\title{
No siempre más es mejor: la diversidad de las redes de innovación en las subsidiarias
}

\author{
Nuria Esther Hurtado-Torres ${ }^{1}$, Blanca Delgado-Márquez, Eulogio Cordón-Pozo, \\ Luis Enrique Pedauga
}

Universidad de Granada, España

doi: 10.20420/eni.2018.212

\begin{abstract}
Resumen
En la actualidad, el papel de las subsidiarias de las empresas multinacionales ha transcendido, pasando de ser meras implementadoras de las innovaciones a contribuidoras directas en el desarrollo de las mismas. Los resultados del trabajo de Delgado y otros (2018) muestran que existe una relación de U invertida entre la diversidad geográfica de la red interna y externa de una subsidiaria y el desarrollo de innovaciones radicales. Además, la diversidad funcional de su red externa también influye en el desarrollo de innovaciones incrementales y radicales.
\end{abstract}

Palabras clave: redes de innovación, innovación incrementa y radial, subsidiarias.

Clasificación JEL: F23, M10, O32.

Agradecimientos: Los autores agradecen el apoyo financiero proporcionado por el Ministerio de Economía y Competitividad (Proyecto ECO2016-75909-P).

Fuente de referencia: Delgado-Márquez, B.L., Hurtado-Torres, N.E., Pedauga, L.E., \& Cordón-Pozo, E. (2018). A network view of innovation performance for multinational corporation subsidiaries. Regional Studies, 52(1), 47-67. DOI: 10.1080/00343404.2016.1272756.

\section{Introducción}

La innovación es, sin duda alguna hoy en día, una de las grandes apuestas de las empresas para seguir siendo eficientes en los entornos actuales caracterizados por una alta globalización. En este contexto global, en el que la innovación es clave para facilitar la competitividad de las empresas, adquiere relevancia analizar qué factores favorecen la innovación en aquellas empresas que desarrollan sus actividades en los mercados internacionales.

Las empresas con presencia en diferentes países, es decir, las empresas multinacionales, presentan una capacidad para generar, asimilar e integrar conocimiento sobre una base mundial que les puede conllevar ventajas en el desarrollo de innovaciones frente a las empresas de ámbito nacional. La encuesta realizada a escala mundial por McKinsey (2011) a un total de 1000 empresas multinacionales a nivel mundial reveló que dos terceras partes de estas empresas, y el $100 \%$ de las empresas top-100 innovadoras, estaban involucradas en actividades de investigación y desarrollo en países foráneos, es decir, desarrollaban actividades innovadoras en sus subsidiarias localizadas en países extranjeros.

Dada la importancia actual del papel jugado por las subsidiarias de las empresas multinacionales en el desarrollo de innovaciones, resulta relevante responder a la siguiente pregunta ¿Influye la diversidad de la red interna y externa de una subsidiaria en el desarrollo de innovaciones por parte de la misma? El trabajo de Delgado, Hurtado, Cordón y Pedauga (2018) trata de aportar luz a la cuestión planteada analizando un panel de datos de 967 subsidiarias españolas de empresas multinacionales.

${ }^{1}$ Autor de correspondencia: nhurtado@ugr.es 


\section{Diversidad de las redes internas y externas de las subsidiarias y su impacto sobre el resultado innovador}

Hasta el momento, la literatura ha destacado que las subsidiarias de las empresas multinacionales pueden operar bajo diferentes mandatos o roles en relación con el desarrollo de innovaciones: el rol de explotación de conocimiento, vinculado con el desarrollo de innovaciones incrementales, y el rol de creación de conocimiento, ligado a la innovación radical. La innovación incremental consiste en pequeñas modificaciones y mejoras que favorecen, en un marco de continuidad, el aumento de la eficiencia o de la satisfacción del usuario o cliente de los productos y procesos. La innovación radical, por su parte, permite el desarrollo de productos y procesos nuevos, completamente diferentes a los que ya existen. Son cambios sustanciales en la tecnología e implican puntos de inflexión para las prácticas existentes.

Tradicionalmente el papel asignado a las subsidiarias ha sido el de explotación de conocimiento, pues dependían, en gran medida, de las competencias de innovación de sus casas matrices. Sin embargo, estudios recientes han subrayado que este papel de las subsidiarias se ha alterado, pasando de ser meras implementadoras de innovaciones a contribuidoras directas en el desarrollo de las mismas. Los estudios empíricos centrados en subsidiarias innovadoras, destacan que el rol que desempeñan depende tanto de las características de los países donde están localizadas, como de peculiaridades de la propia subsidiaria, incluyendo los recursos disponibles o su tamaño. Además, la integración dual de las subsidiarias de las empresas multinacionales, por un lado, en la red interna de la propia multinacional y, por otro lado, en las redes externas locales e internacionales, puede generar efectos positivos en el desarrollo de innovaciones (Achcaoucaou, Miravitlles \& León-Darder, 2014).
Delgado y otros (2018) analizan la influencia de la diversidad de la red interna y externa en el desarrollo de innovaciones incrementales y radicales. Dicha diversidad conlleva similitudes y/o diferencias en relación al conocimiento tecnológico, cultura, entorno institucional o cultura organizativa de los miembros de la red. Además, la mayor o menor diversidad implicará distintos niveles de proximidad/distancia cognitiva entre la subsidiaria y los miembros de sus redes (Nooteboom Van Haverbeke, Duysters, Gilsing \& Van den Oord, 2007).

En lo que respecta a la red interna de una subsidiaria, la misma estará formada por las otras unidades pertenecientes a la misma empresa multinacional y, por tanto, existe una proximidad organizativa entre los miembros de esta red que pertenecen a la misma empresa y comparten una cultura organizativa. Sin embargo, estas unidades pueden estar ubicadas en diferentes países, por lo que presentan una distancia cognitiva como consecuencia de las diferencias culturales e institucionales entre países. Por otro lado, la red externa puede estar integrada por agentes muy diversos tales como clientes, proveedores, institutos de investigación y otras instituciones externas que poseen bases de conocimiento diferente. Además, estos miembros de la red externa pueden presentar también diferencias cognitivas derivadas de estar ubicadas en diferentes países.

Los resultados del trabajo de Delgado y otros (2018) muestran que existe esa relación de U invertida entre la diversidad geográfica de la red interna y externa de una subsidiaria y el desarrollo de innovaciones radicales. Si estas redes están más diversificadas geográficamente, la subsidiaria deberá hacer frente a posibles deseconomías de escala, incrementos en los costes de coordinación en sus procesos de aprendizaje y, por tanto, esto podrá conllevar una disminución de su capacidad para transformar el conocimiento adquirido a través de sus redes en innovación radical. No obstante, un énfasis 
excesivo en redes locales, es decir, otras unidades de la empresa multinacional o socios externos localizadas en el mismo país de la subsidiaria, puede tener como consecuencia una limitación importante en la obtención de conocimientos suficientemente diferentes o novedosos para la subsidiaria $\mathrm{y}$, por tanto, de conocimientos útiles para desarrollar innovaciones radicales. Los resultados difieren en lo que respecta al desarrollo de innovaciones incrementales, puesto que en este caso no se identifica una relación entre diversidad geográfica y desarrollo de este tipo de innovaciones.

Por otro lado, los resultados de Delgado y otros (2018) también confirman que la relación entre la diversidad funcional de la red externa de la subsidiaria (determinada por una mayor o menor diversidad de agentes tales como, clientes, proveedores, institutos de investigación) y el desarrollo de innovaciones de la subsidiaria presenta la forma $\mathrm{U}$ invertida, existiendo un nivel óptimo de diversificación funcional. Puesto que los agentes que integran la red externa presentan diferentes bases de conocimiento, la mayor diversidad puede dificultar la interpretación y asimilación del conocimiento transmitido entre los miembros de la red. Al mismo tiempo, si la diversidad es demasiado reducida, la cooperación no garantiza el acceso a nuevos conocimientos que le permita desarrollar innovaciones.

\section{Conclusiones}

De este trabajo se derivan importantes sugerencias de carácter práctico para las empresas y administraciones públicas. En primer lugar, se comprueba que el desarrollo de innovaciones radicales e incrementales de las subsidiarias está influenciado por la diversidad geográfica y funcional que caracteriza sus redes interna y externa. Por tanto, este estudio sugiere la importancia del doble contexto de integración de las subsidiarias en redes internas y externas de conocimiento para el desarrollo de innovaciones.

En segundo lugar, dado que la diversidad de estas redes puede condicionar el resultado de dicha colaboración, se deben de buscar el nivel óptimo de diversidad que le permita mejorar el desarrollo de innovaciones incrementales y radicales. En particular, la diversidad geográfica de la red interna y externa y la diversidad funcional de su red externa influyen de forma significativa en el desarrollo de innovaciones a nivel de subsidiarias. Esto nos permite concluir que no sólo la diversificación internacional de la empresa multinacional, a la que pertenece la subsidiaria, sino también el alcance geográfico y funcional de su red externa pueden facilitar el acceso a conocimientos heterogéneos que favorecen el desarrollo de innovaciones. No obstante, la influencia de la diversidad de la red no es fija, sino que depende del tipo de la innovación llevada a cabo.

\section{Referencias}

Achcaoucaou, F., Miravitlles, P., \& León-Darder, F. (2014). Knowledge sharing and subsidiary R\&D mandate development: A matter of dual embeddedness. International Business Review, 23(1), 76-90.

Delgado-Márquez, B.L.; Hurtado-Torres, N.E; Pedauga, L.E.; \& Cordón-Pozo, E. (2018). A network view of innovation performance for multinational corporation subsidiaries. Regional Studies, 52(1), 4767. DOI: 10.1080/00343404.2016.1272756.

Fitjar, R. D., Huber, F., \& Rodríguez-Pose, A. (2016). Not too close, not too far: testing the Goldilocks principle of 'optimal'distance in innovation networks. Industry and Innovation, 23(6), 465-487.

McKinsey (2011). R\&D strategies in emerging economies: McKinsey Global Survey Results. En http://www.mckinsey.com/insights/operations/r_and _38d_strategies_in_emerginG_economies_mckinsey _global_survey_results.

Nooteboom, B., Van Haverbeke, W., Duysters, G., Gilsing, V., \& van den Oord, A. (2007). Optimal cognitive distance and absorptive capacity. Research Policy, 36(7), 1016-1034. 


\title{
More is not always better: The diversity of innovation networks in subsidiaries
}

\author{
Nuria Esther Hurtado-Torres ${ }^{1}$, Blanca Delgado-Márquez, Eulogio Cordón-Pozo, \\ Luis Enrique Pedauga \\ Universidad de Granada, Spain
}

\begin{abstract}
The role of the subsidiaries of multinational companies has evolved from merely implementing innovation to directly contributing to the development of innovation. The work of Delgado and others (2018) shows that there is an inverted-U relationship between the geographic diversity of the internal and external networks of a subsidiary and the development of radical innovation. In addition, the functional diversity of a subsidiary's external network also influences the development of incremental and radical innovation.
\end{abstract}

Keywords: Innovation networks, incremental and radical innovation, MNC subsidiaries.

JEL classification: F23, M10, O32.

Acknowledgements: Financial support from the Spanish Ministry of Economy and Competitiveness (Projects: ECO201675909-P) is gratefully acknowledged.

Reference source: Delgado-Márquez, B.L., Hurtado-Torres, N.E., Pedauga, L.E., \& Cordón-Pozo, E. (2018). A network view of innovation performance for multinational corporation subsidiaries. Regional Studies, 52(1), 47-67. DOI: 10.1080/00343404.2016.1272756.

\section{Introduction}

Without a doubt, innovation is today one of the major elements on which companies must rely to remain efficient in environments characterized by a high level of globalization. In this global context in which innovation is key to facilitating competitiveness, it becomes relevant to analyze which factors favor innovation in companies active in international markets.

Companies with a presence in different countries, that is, multinational companies, have the capacity to generate, assimilate and integrate knowledge on a global basis. This can provide an advantage to multinationals versus national companies in the development of innovation. McKinsey's (2011) worldwide survey of 1,000 multinational companies revealed that two thirds of these companies, and $100 \%$ of the top- 100 most innovative companies, were involved in research and development activities in foreign countries; they developed innovative activities in their subsidiaries located in foreign countries.

Given the current importance of the role played by the subsidiaries of multinational companies in the development of innovation, it is relevant to answer the following question: Does the diversity of the internal and external networks of a subsidiary influence the development of innovation? The work by Delgado, Hurtado, Cordón and Pedauga (2018) seeks to evaluate this question by analyzing a data panel of 967 Spanish subsidiaries of multinational companies.

${ }^{1}$ Corresponding author: nhurtado@ugr.es 
2 Diversity of the internal and external networks of subsidiaries and their impact on innovative outcomes

To date, the literature has stressed that subsidiaries of multinational companies can operate under different mandates or play different roles in relation to the development of innovation: the role of exploiting knowledge, which is linked to the development of incremental innovation, and the role of creating knowledge, which is linked to radical innovation. Incremental innovation consists of small modifications and improvements that favor, in a framework of continuity, increases in efficiency or the satisfaction of the user or customer of the products and processes. Radical innovation, on the other hand, consists of the development of new products and processes completely different from those that already exist. Radical innovation enables substantial changes in technology that can represent turning points in existing practices.

Traditionally, the role assigned to subsidiaries has been to exploit knowledge because they depended, mostly, on the innovation competences of their parent companies. However, recent studies have stressed that this role has changed, with subsidiaries evolving from merely implementing innovation to directly contributing to the development of innovation. The empirical studies focused on innovative subsidiaries emphasize that the role they play depends both on the characteristics of the countries where they are located and on the peculiarities of the subsidiary itself, including its size and available resources. In addition, the dual integration of subsidiaries of multinational companies into both the internal network of the multinational itself and into local and international external networks can generate positive effects on the development of innovation (Achcaoucaou, Miravitlles \& León-Darder, 2014).
The work of Delgado and others (2018) analyzes the influence of the diversity of subsidiaries' internal and external networks on the development of incremental and radical innovation. This diversity entails similarities and/or differences in the technological knowledge, culture, institutional environment and organizational culture of the members of the network. In addition, different levels of diversity imply different levels of cognitive proximity or distance between the subsidiary and the members of its networks (Nooteboom Van Haverbeke, Duysters, Gilsing \& Van den Oord, 2007).

The internal network of a subsidiary is formed by the other units belonging to the same multinational company, and therefore there is an organizational proximity between the members of this network that belong to the same company and share an organizational culture. However, these units can be located in different countries; thus, there is a cognitive distance between them because of cultural and institutional differences between countries. Regarding the external network, it can be composed of very diverse agents such as customers, suppliers, research institutes and other external institutions that have different knowledge bases. Members of the external network can also present cognitive differences derived from being located in different countries.

The work of Delgado and others (2018) shows that there is an inverted-U relationship between the geographic diversity of the internal and external networks of a subsidiary and the development of radical innovation. If these networks are more geographically diversified, then the subsidiary faces possible diseconomies of scale and greater costs of coordination of its learning processes, which could undermine its capacity to transform the knowledge acquired through its networks into radical innovation. However, an excessive emphasis on local networks, that is, other units of the multinational company or external partners located in the same 
country as the subsidiary, may lead to important limitations for the subsidiary in obtaining significantly different or new and therefore useful knowledge to develop radical innovation. These results differ from the development of incremental innovation because a relationship between geographical diversity and the development of this type of innovation has not been identified.

The work of Delgado and others (2018) also confirms that the relationship between the functional diversity of the subsidiary's external network (determined by a greater or lesser diversity of agents such as clients, suppliers, and research institutes) and the development of innovation by the subsidiary has an inverted-U shape, whereby there exists an optimal level of functional diversification. Because the agents that make up the external network present different knowledge bases, too great a level of diversity can hinder the interpretation and assimilation of knowledge transmitted among the members of the network. At the same time, if diversity is too limited, cooperation does not guarantee access to new knowledge facilitating the development of innovation.

\section{Conclusions}

This work provides important practical suggestions for companies and public administrations. First, it shows that the development of radical and incremental innovation by subsidiaries is influenced by the geographical and functional diversity that characterizes their internal and external networks. Therefore, this study suggests the importance of the double context of integration of subsidiaries into internal and external knowledge networks for the development of innovation.

Second, given that the diversity of these networks can determine the result of such collaboration, subsidiaries must seek the optimum level of diversity that allows them to improve the development of incremental and radical innovation. Both the geographical diversity of internal and external networks and the functional diversity of the external network have a significant influence on the development of innovation at the subsidiary level. This allows us to conclude that facilitating access to heterogeneous knowledge that favours the development of innovation depends not only on the international diversification of the multinational company to which the subsidiary belongs but also on the geographic and functional scope of the subsidiary's external network. However, the influence of network diversity is not fixed but depends on the type of innovation carried out.

\section{References}

Achcaoucaou, F., Miravitlles, P., \& León-Darder, F. (2014). Knowledge sharing and subsidiary R\&D mandate development: A matter of dual embeddedness. International Business Review, 23(1), 76-90.

Delgado-Márquez, B.L.; Hurtado-Torres, N.E; Pedauga, L.E.; \& Cordón-Pozo, E. (2018). A network view of innovation performance for multinational corporation subsidiaries. Regional Studies, 52(1), 4767. DOI: 10.1080/00343404.2016.1272756.

Fitjar, R. D., Huber, F., \& Rodríguez-Pose, A. (2016). Not too close, not too far: testing the Goldilocks principle of 'optimal'distance in innovation networks. Industry and Innovation, 23(6), 465-487.

McKinsey (2011). R\&D strategies in emerging economies: McKinsey Global Survey Results. In http://www.mckinsey.com/insights/operations/r_and _38d_strategies_in_emerginG_ economies_mckinsey_global_survey_results.

Nooteboom, B., Van Haverbeke, W., Duysters, G., Gilsing, V., \& van den Oord, A. (2007). Optimal cognitive distance and absorptive capacity. Research Policy, 36(7), 1016-1034. 